\title{
Polymorphisms of the serotonin transporter and receptor genes: susceptibility to substance abuse
}

\author{
This article was published in the following Dove Press journal: \\ Substance Abuse and Rehabilitation \\ 19 June 2012 \\ Number of times this article has been viewed
}

\author{
Aryeh I Herman \\ Kornelia N Balogh \\ Department of Psychiatry, VA \\ Connecticut Healthcare/Yale \\ University School of Medicine, \\ West Haven, CT, USA
}

Correspondence: Aryeh Herman Department of Psychiatry, VA Connecticut Healthcare/Yale University School of Medicine, 950 Campbell Avenue, West Haven, CT 065I6, USA Tel + I 2039323486 ext 7432 Fax + I 2039373472 Email aryeh.herman@yale.edu

\begin{abstract}
Serotonin (5-hydroxytryptamine [5-HT]) is an important neurotransmitter implicated in regulating substance-use disorder (SUD) acquisition, maintenance, and recovery. During the past several years, an abundance of research has begun discovering and describing specific 5-HT genetic polymorphisms associated with SUDs. Genetic variations in the 5-HT system, such as SLC6A4, HTR1B, HTR2A, HTR2C, HTR3 (HTR3A, HTR3B, HTR3C, HTR3D, and HTR3E), likely play a role contributing to SUD patient heterogeneity. The 5-HT transporter-linked polymorphic region $\mathrm{S}$ allele, located in SLC6A4, has now been modestly associated with alcohol dependence in two large meta-analyses. Additional 5-HT genes may also play a role but have not been extensively investigated. A limited number of SUD treatment studies have included 5-HT gene variation as moderating treatment outcomes, but the results have been equivocal. Future research on 5-HT addiction genetics should adopt whole-genome sequencing technology, utilize large study samples, and collect data from multiple ethnic groups. Together, these methods will build on the work already conducted with the aim of utilizing 5-HT genetics in SUD treatment settings.
\end{abstract}

Keywords: serotonin, genetic, substance dependence, addiction, alcohol, drug

\section{Introduction}

Substance use disorders (SUDs) have severe negative effects on addicts, their families, communities, the economy, and society. The National Survey on Drug Use and Health reported that in $2008,14.2 \%$ of individuals 12 years of age and older had used illicit drugs during the past year. ${ }^{1}$ The Federal Bureau of Investigation shows that $12.2 \%$ of more than 14 million arrests in 2008 were for drug violations, the most common arrest crime category. ${ }^{2}$ Fifty-three percent of state and $45 \%$ of federal prisoners met Diagnostic and Statistical Manual for Mental Disorders (DSM) criteria for SUDs. ${ }^{3}$ The annual financial cost of drug use disorders and alcohol abuse in the United States is estimated to be $\$ 180$ billion and $\$ 184$ billion, respectively. ${ }^{4}$ Addiction research focused on serotonin (5-HT) genetics has begun clarifying specific gene polymorphisms associated with specific SUDs and related behaviors. In the future, these 5-HT variants may inform individualized choices of treatment, ultimately reducing SUD-related problems for patients as well as the enormous public health burden caused by addictions. ${ }^{5,6}$

\section{Polymorphisms of the serotonin transporter and receptor genes}

Addiction susceptibility is influenced by both biological and environmental systems. Altered 5-HT transmission is thought to increase susceptibility to a wide range of SUDs. ${ }^{7}$ 
The 5-HT system is highly complex, composed of neural communication mediated by multiple pre- and postsynaptic 5-HT receptor subtypes as well as a 5-HT transporter system that brings 5-HT back into the presynaptic neuron. ${ }^{8}$ Genetic polymorphisms throughout each of these 5-HT-related genes collectively give rise to unique genetic architecture, which may ultimately contribute towards an individual's addiction risk, disease trajectory, and treatment recovery (Table 1).

\section{SLC6A4 and substance use disorders}

The 5-HT transporter (5-HTT) protein plays a central role in the 5-HT system by regulating the reuptake of 5-HT following synaptic release. Multiple drugs of abuse have been shown to interact functionally with 5-HTT., ${ }^{9,10}$ The 5-HTT is encoded by a single gene (SLC6A4) on chromosome 17q11.1-17q12 and contains two well-studied polymorphisms associated with susceptibility to SUDs. A common promotor polymorphism (5-HTTLPR) ${ }^{11}$ with two common alleles, a long allele with 16 repeats (L) and a short allele with 14 repeats $(\mathrm{S})$, as well as other ethnic-specific variants that occur at much lower frequency, modulates 5-HTT expression with the $\mathrm{S}$ allele associated with reduced SERT transcriptional activity in vitro. ${ }^{11}$ STin2 VNTR, a second well-studied polymorphism of SLC6A4, consists of a17-bp variable number of tandem repeats with four different alleles that correspond to the number of tandem repeats $(12,10,9$, or 7 ), with the 12 and 10 most frequently observed. ${ }^{12}$ The STin2.12 allele has been reported to be a transcriptional enhancer. ${ }^{11,13-15}$ Given the importance of SLC6A4 in the 5-HT system, these polymorphisms, most of which focus on 5-HTTLPR, have been investigated as related to SUDs.

\section{Alcohol}

Feinn et $\mathrm{al}^{16}$ performed a systematic investigation of 17 published studies (including 3489 alcoholics and 2325 controls, primarily of European ancestry) and found that the frequency of the S allele at 5-HTTLPR was significantly associated with alcohol dependence (AD). The effect size was increased in individuals with a comorbid psychiatric condition, early onset or more severe AD subtype. Subsequent to the Feinn et al ${ }^{16}$ report, Hu et al (2006) described an A/G (rs25531) single-nucleotide polymorphism (SNP) within the 5-HTTLPR $\mathrm{L}$ rendering it triallelic $\left(\mathrm{L}_{\mathrm{A}}, \mathrm{L}_{\mathrm{G}}, \mathrm{S}\right)$. The $\mathrm{L}_{\mathrm{A}}$ is associated with high levels of 5-HTT mRNA transcription in vitro, whereas the $\mathrm{L}_{\mathrm{G}}$ is more similar to $\mathrm{S}$ allele, with low levels of 5-HTT mRNA. ${ }^{17}$ The most recent studies investigating 5-HTTLPR and its relationship to SUDs, mainly AD, have typically analyzed 5-HTTLPR as triallelic. ${ }^{18}$ Additionally, larger study

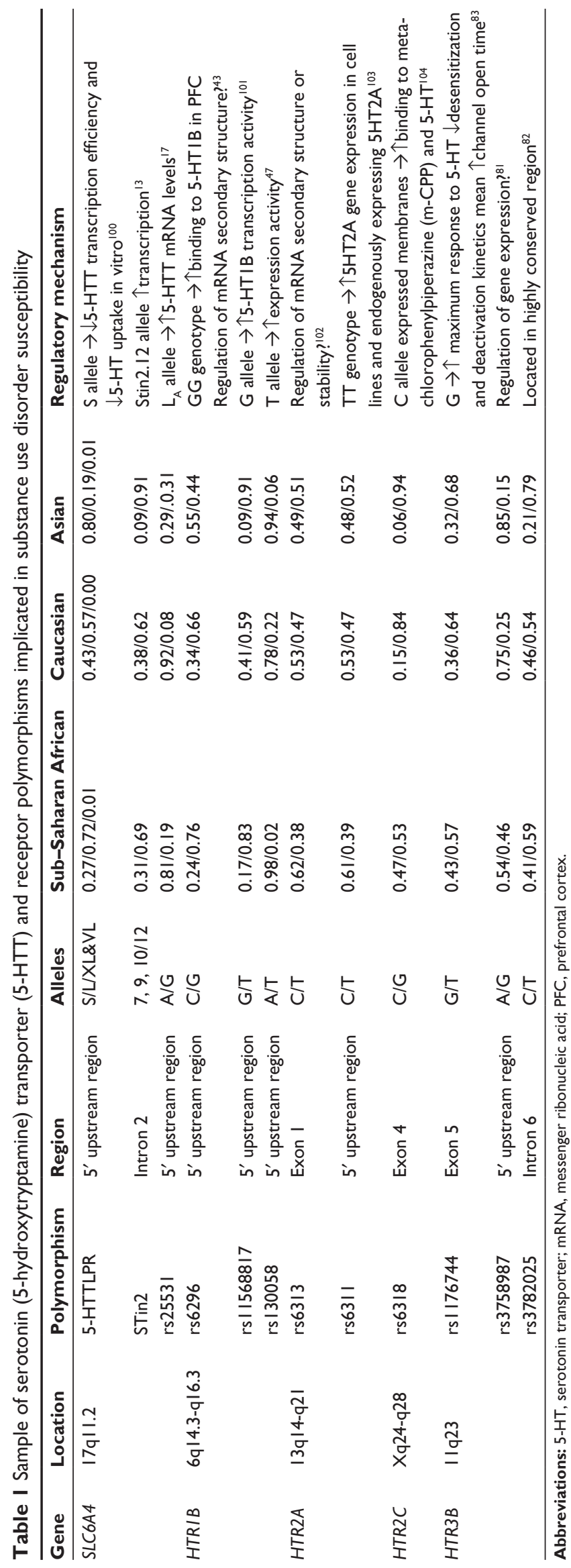


samples, enhanced population specificity, and inclusion of negative life events such as early childhood trauma continue to clarify the relationship between 5-HTTLPR and AD. ${ }^{18-21}$ Because publications on the link between 5-HTTLPR and AD had almost doubled since the Feinn et al report, McHugh et al (2010) conducted a follow-up meta-analysis of 22 studies that included 8050 participants. A significant association between $\mathrm{AD}$ diagnosis and the presence of at least one $\mathrm{S}$ allele was found with slightly stronger results for participants who had two copies of the $\mathrm{S}$ allele. ${ }^{22}$ Relatively fewer studies have investigated the association between STin2 and AD and the research that has been conducted has produced equivocal results. $^{23,24}$

\section{Other drugs of abuse}

SLC6A4 polymorphisms have been studied as related to nicotine dependence (ND), cocaine dependence (CD), and opioid dependence (OD), but altogether these studies are relatively fewer than on AD. Of the studies investigating the association between 5-HTTLPR and nicotine, some have shown the association with the L allele, ${ }^{25-28}$ others have shown the effect with the S allele, ${ }^{29-31}$ and several more have not observed any effects at all. ${ }^{18,32,33}$ The association between SLC6A4 (5-HTTLPR and STin2) and OD or CD are also mixed. ${ }^{24,34-37}$ Until more research is conducted, the relationship between these drug use disorders and SLC6A4 remains unclear.

\section{$H T R I B$ and substance use disorders}

The 5-HT1B receptors are widely distributed throughout the brain. The 5-HT1B heteroreceptors are found mainly on gamma-aminobutyric acid (GABA) terminals projecting from the nucleus accumbens to the ventral tegmental area, pathways thought to have importance for drug reward. ${ }^{38}$ The human HTR1B gene, located at 6q14.3-q16.3, is intronless and encodes a 390 -amino-acid polypeptide. ${ }^{39}$ While several $H T R 1 B$ gene variants have been investigated as related to SUDs, rs6296 (G861C,Val3Val), a synonymous SNP in exon 1 , is the best-studied gene variant. ${ }^{40}$ The function of this variant is unknown, but it may influence the secondary structure of RNA. ${ }^{41}$

\section{Alcohol}

Lappalainen et al (1998) examined the role of HTR $1 B$ rs6296 in vulnerability to AD with antisocial personality disorder (ASPD) and intermittent explosive disorder. ${ }^{42}$ The frequency of rs6296 C allele was observed to be elevated in Finns with antisocial alcoholism. In an American
Indian replication sample, HTR $1 B$ rs6296 showed significant linkage to antisocial AD. Shortly following this work, Huang et al (1999) studied 5-HT1B receptor binding in a sample of patients with heterogeneous psychopathology, some of whom had a history of SUDs. ${ }^{43}$ Though the results did not support an association between the rs6296 and AD, they did observe that the $\mathrm{C}$ allele of rs6296 had lower 5-HT1B receptor binding as measured by $\mathrm{B}_{\max }$ values in postmortem human brain. Subsequent reports have attempted to clarify this signal as related to $\mathrm{AD}$, with equivocal results. ${ }^{41,44,45}$ Kranzler et al (2002) studied linkage disequilibrium (LD) across three HTR1B polymorphic sites (rs11568817 [G-261T], rs6296, rs6298 [C129T]) and found no evidence for allelic association with AD and SUDs in general, alone or with a comorbid ASPD diagnosis. ${ }^{46}$ Sun et al (2002) sequenced $H T R 1 B$ in a Taiwanese Han sample of individuals with $\mathrm{AD}$ and controls. ${ }^{47}$ Among several variants identified, rs130058 (A-161T) T allele was significantly higher in AD cases than in controls and was demonstrated, in vitro, to have higher expression than the A allele. Cao et al (2011) also found that the $T$ allele of rs130058 was associated with $\mathrm{AD}$ as well as a younger age of onset of AD in a Chinese Han sample. ${ }^{48}$ Recently, larger studies have reported additional SNPs in HTR $1 B$ as related to AD. More work should be conducted to replicate these signals and clarify how these variants relate to the better-characterized SNPs. ${ }^{49,50}$ Interestingly, a functional HTR IB SNP (rs13212041) located in a microRNA binding site has been described and reported to account for a larger proportion of variation in self-reported anger and hostility compared with well-known HTR 1B SNPs described above. ${ }^{51}$ To our knowledge, rs13212041 has not been extensively studied as related to $\mathrm{AD}$ and warrants further investigation.

\section{Other drugs of abuse}

Some workers have investigated whether HTR $1 B$ genetics is related to SUDs other than AD. Cigler et al (2001) studied $H T R 1 B$ gene variants in 210 individuals with a primary diagnosis (DSM-IV criteria) of CD or abuse, AD or abuse, and controls. Of the seven HTR $1 B$ polymorphisms studied, including rs6296, there was no association found.$^{52}$ Israeli female college students who carried two copies of the $\mathrm{G}$ allele at rs6296 were observed to have higher levels of ND. ${ }^{53}$ Ujike et al (2011) conducted a small case-control study of methamphetamine dependence in a Japanese sample. No association between HTR1B SNPs (rs130058, rs1228814, and rs1228814) and methamphetamine dependence was observed. ${ }^{54}$ 


\section{HTR2A and substance use disorders}

The 5-HT2A receptor is a ubiquitous G-protein-coupled receptor that is distributed widely throughout the central nervous system in mammals. ${ }^{55,56}$ 5-HT2A receptors have been shown to modulate dopamine neurotransmission, ${ }^{57,58}$ making it a target for substance use susceptibility. The $H T R 2 A$ gene is located in the chromosomal region 13q14-q21. Though the HTR2A gene is highly polymorphic, the majority of addiction genetic research has focused on two SNPs - rs6311 (A-1438G) and rs6313 (T102C). These two SNPs are reported to be in linkage disequilibrium. The rs6311 SNP is located upstream of two alternative promoters for HTR2A and may affect the promoter activity and alter the expression of HTR2A in the brain. ${ }^{59}$ The rs6313 SNP is in exon 1 of the HTR2A and codes the 34th amino acid as serine.

\section{Alcohol}

A small positive association was reported between the $\mathrm{G}$ allele of rs6311 in Japanese alcoholics with inactive ALDH2 compared with control subjects. ${ }^{60} \mathrm{~A}$ second study investigating rs6311 in a sample of individuals with $\mathrm{AD}$, OD, and healthy controls observed that individuals with $\mathrm{AD}$, compared with $\mathrm{OD}$, were significantly enriched with the $\mathrm{G}$ allele, but only when they carried the 5-HTTLPR L allele. ${ }^{24}$ SNP rs6313 was not observed to moderate response to alcohol in a small sample comparing low- and high-level alcohol responders ${ }^{61}$ nor was it found to be associated with AD patients compared to nonconsanguineous relatives. ${ }^{62}$

\section{Other drugs of abuse}

The influence of 5-HTR $2 A$ gene variation has also been studied in several other SUDs. The HTR2A rs6311 A allele was associated with cigarette smokers compared with nonsmoking controls in a sample of AD European-derived Brazilians. ${ }^{63}$ HTR2A rs6313 was unrelated to smoking phenotypes in a large sample of young adults that included smoking status and nicotine level. ${ }^{64}$ Studies conducted thus far in OD have not observed an association with $H T R 2 A,{ }^{24,65}$ and studies linking this gene with $\mathrm{CD}$ have not been thoroughly investigated. Interestingly, rs6311 was recently considered as a potential moderator of medication overuse headache, a chronic headache caused by excessive use of medication taken for symptomatic headache. Though the results of the study were mainly negative, a second HTR $2 A$ SNP, rs6305 (C516T), was related to monthly drug consumption in medication overuse headache patients and possibly drug-seeking behavior. ${ }^{66}$

\section{HTR2C and substance use disorders}

5-HT2C receptors are densely expressed throughout multiple brain regions, and have been shown to modulate discriminative stimulus effects of cocaine. ${ }^{67-69}$ The HTR2C gene is located at the Xq24-q28 chromosomal band. ${ }^{70}$ Limited research supports the role of HTR2C sequence variation and SUDs. Lappalainen et al (1995) discovered rs6318 (Cys23Ser) encoding a missense mutation at codon 23 of the Cys-to-Ser substitution in a Caucasian population. ${ }^{71}$ Interest in rs6318 developed following the observation that the Ser substitution was associated with 3-methoxy-4-hydroxyphenylglycol (MHPG), a metabolite of norepinephrine degradation, both in $\mathrm{AD}$ violent offenders and population controls. The same study was unable to detect any association between rs6318 and AD or alcohol abuse. ${ }^{72}$ Subsequently, the association between rs6318 and MHPG was not replicated, ${ }^{73}$ and several other studies failed to find a relationship between rs6318 and AD. ${ }^{61,74}$ Mottagui-Tabar et al (2004) reported that none of the four HTR2C promoter SNPs investigated nor the promoter microsatellite were shown to be associated with $\mathrm{AD} .^{75}$

\section{HTR3 and substance use disorders}

The 5-HT3 receptor is the only ligand-gated ion channel in the 5-HT receptor family and may play a role in reward by modulating dopamine release in the mesolimbic pathway. ${ }^{76,77}$ GABA(A) and glycine ligand-gated ion channel receptors, sharing structural and functional homology to 5-HT3 receptors, are targets for the acute and chronic effects of alcohol. ${ }^{78} H T R 3$ genes reside in close proximity on chromosome 11q23 (HTR3A and HTR3B) and 3q27 (HTR3C, $H T R 3 D$, and HTR $3 E$ ) in the human genome. ${ }^{79,80}$ Relatively few studies have investigated the association between HTR 3 genetics and SUDs. Levran et al (2008) studied 1350 variants in 130 candidate genes in patients with a past history of severe HD and compared them with healthy controls with no history of drug abuse. The $\mathrm{C}$ allele of rs3758987 in HTR $3 B$ gave a nominally significant association with OD. This SNP is located at the gene regulatory region and may impact gene expression. ${ }^{81}$ In a multisite study, the A allele of an intronic HTR3B SNP rs3782025 was associated in individuals with both $\mathrm{AD}$ and $\mathrm{ASPD}$ in a Finnish sample, but not in Bethesda and Plains Indian samples. ${ }^{82}$ A recently published study found that an HTR $3 B$ missense polymorphism rs1176744 (Tyr129Ser) predicted AD and was also related to AD and SD together. ${ }^{83}$ The Ser129 variant of rs1176744 substitution that was associated with $\mathrm{AD}$ has been shown to expand maximum response to 5-HT, lower desensitization 
and deactivation kinetics, and increase mean channel open time. ${ }^{84,85}$ The rs 1176744 has also been shown to be in strong linkage disequilibrium with rs3782025.

\section{5-HT genetics and substance use disorder treatment}

5-HT genetics are not currently part of any approved and empirically based addiction treatment algorithm. However, optimism remains about potential clinical use of 5-HT genetics, as well as genes from other relevant systems (eg, dopamine, GABA, norepinephrine, opioid, etc) to treat SUDs. Embracing 5-HT genetic variations could impact treatment in three key ways. First, improved characterization of 5-HT genetics could lead towards personally optimizing addiction medications, especially drugs targeting the 5-HT system. This genetic information could be useful in predicting the therapeutic efficacy of certain medications as well as their side-effect profile, allowing for more precise treatment. Second, enhanced characterization of 5-HT variants, along with other gene systems, will lead towards more accurate SUD diagnosis. For example, 5-HT variants could predict executive cognitive functioning or externalizing traits that may influence relapse proneness via general neurobehavioral mechanisms, thus could have significant treatment moderating effects. ${ }^{86}$ Third, enhanced understanding of 5-HT gene variation could lead towards earlier identification and intervention, potentially resulting in fewer negative consequences to the individual at risk and society.

\section{Alcohol}

Animal studies and human clinical laboratory paradigms suggest that ondansetron, a 5-HT3 antagonist, has potential clinical utility for treating $\mathrm{AD}$, but its efficacy varies widely. Research has investigated 5-HT genetics to better clarify AD ondansetron responders versus nonresponders. A randomized controlled treatment study indicated that individuals with $\mathrm{AD}$ treated with ondansetron and who were also homozygous for 5-HTTLPR L allele had fewer numbers of drinks per drinking day and a higher percentage of days of total abstinence. This pharmacogenetic effect was enhanced by including rs1042173, an SNP in the 3' untranslated region of the $S L C 6 A 4$ transcript ${ }^{87-90}$ Kenna et al (2009) also observed that ondansetron improved drinking outcomes in nontreatment-seeking AD subjects carrying the L/L genotype compared with those with the L/L genotype receiving sertraline, a selective serotonin reuptake inhibitor (SSRI), who slightly increased their drinking. ${ }^{91}$ Kranzler et al (2012) conducted a 12-week double-blind randomized trial of sertraline for AD and genotyped individuals for 5-HTTLPR. In drinkers with late-onset $\mathrm{AD}$, those taking sertraline, who also had the L allele, had better drinking outcomes (fewer drinking and heavy drinking days). Conversely, those with early onset $\mathrm{AD}$ and who carried the $\mathrm{L}$ allele had better drinking outcomes when treated with placebo. ${ }^{92} \mathrm{~A}$ recent study in patients with comorbid major depression and $\mathrm{AD}$ treated with escitalopram, an SSRI, indicated no 5-HTTLPR genotype effect on the Alcohol Use Disorders Identification Test as compared with memantine, a nonserotonergically acting medication. ${ }^{93}$ Wong et al (2008) conducted a small study to determine whether 5-HTTLPR and 5HT2C rs6318 moderated the influence of citalopram, an SSRI, on adrenocorticotrophic hormone levels in males with $\mathrm{AD}$ and controls. Both $\mathrm{AD}$ and control groups with Ser23 alleles had significantly higher adrenocorticotrophic hormone responses during placebo administration and attenuated the responses under citalopram administration. ${ }^{94}$

\section{Other drugs of abuse}

Mannelli et al (2005) did not observe a 5-HTTLPR-moderating effect of cocaine use in a sample of African-American $\mathrm{CD}$ patients during a behaviorally oriented outpatient treatment for $\mathrm{CD} .{ }^{35}$ To date, 5 -HT genetic moderators of OD treatment studies have not been conducted. However two studies, one investigating postoperative analgesic requirements after major abdominal surgery and the second looking at analgesic response to remifentanil, a potent synthetic opioid analgesic drug, provide weak evidence for investigating 5-HT genetics in future OD treatment research..$^{95,96}$ Despite the apparent importance of 5-HT neurotransmission to smoking cessation, three studies investigating the influence of 5-HTTLPR on the outcome of NRT found no association between genotype and abstinence at the end of NRT treatment. ${ }^{97-99}$ David et al (2008) also studied other 5-HT gene variants (5-HTTLPR, rs1799913, rs6295) that were not associated with abstinence following NRT either. ${ }^{99}$

\section{Conclusion}

Given that the 5-HT system is modulated by all of the major classes of drugs of abuse, better characterization of 5-HT gene variation would help increase the potential to identify patients with SUD earlier and perhaps prior to illness onset, develop more refined diagnostics, and improve treatment outcomes. However, understanding how the relationship between individual 5-HT genetic architecture relates to SUD remains in its infancy, and several of the markers described here only equivocally associate with SUDs. 
Many of the studies described were small $(<500)$, focused on only a few 5-HT SNPs, and were conducted in primarily Caucasian samples. Any single 5-HT SNP marker accounts for a relatively small portion of the variation in SUDs. Based on this literature review, 5-HTTLPR S allele appears to exhibit the strongest association with SUD, specifically AD. However 5-HTTLPR is also the best-studied 5-HT polymorphism. Perhaps other 5-HT polymorphisms contribute equally or even more to SUD than 5-HTTLPR, but have not been as thoroughly investigated. The studies reviewed above provide a foundational link between 5-HT genetics and SUDs. The next step towards translating SUD and 5-HT genetic research into true clinical applications will benefit from embracing whole-genome sequencing to analyze the majority of 5-HT genetic variation in a single project, capitalizing on large publicly available data sets to significantly increase the sample size of any given study, and examining samples drawn from genetically distinct ethnic ancestries. These enhanced study methods in concert with work described in this review provide hope that in the future 5-HT genetics, as well as other variants from other gene systems, will be used to better understand better SUD presentation variability and disease course while increasing treatment response.

\section{Acknowledgments}

We gratefully acknowledge Jonathan Covault, $\mathrm{MD}, \mathrm{PhD}$ for his comments and suggestions on this manuscript. This work was supported by NIDA K12 DA00167 (AH) and NIDA RO1 DA023230 (KB) grants.

\section{Disclosure}

The authors declare that there is no conflict of interest.

\section{References}

1. Substance Abuse and Mental Health Services Administration. Results from the 2008 National Survey on Drug Use: National Findings. Rockville: Office of Applied Studies; 2009.

2. National Drug Intelligence Center. National Drug Threat Assessment 2010. Johnstown: National Drug Intelligence Center; 2010.

3. Mumola CJ, Karberg JC. Drug Use and Dependence, State and Federal Prisoners, 2004. Washington: Bureau of Justice Statistics; 2006.

4. Office of National Drug Control Policy. The Economic Costs of Drug Abuse in the United States, 1992-2002. Washington: Executive Office of the President; 2004.

5. World Health Organization. Neuroscience of Psychoactive Substance User and Dependence. Geneva: WHO; 2004

6. Edenberg HJ, Kranzler HR. The contribution of genetics to addiction therapy approaches. Pharmacol Ther. 2005;108(1):86-93.

7. Cox SM, Benkelfat C, Dagher A, et al. Effects of lowered serotonin transmission on cocaine-induced striatal dopamine response: PET [(1) (1)C] raclopride study in humans. Br J Psychiatry. 2011;199:391-397.
8. Lesch KP, Mossner R. Genetically driven variation in serotonin uptake: is there a link to affective spectrum, neurodevelopmental, and neurodegenerative disorders? Biol Psychiatry. 1998;44(3):179-192.

9. Little KY, McLaughlin DP, Zhang L, et al. Cocaine, ethanol, and genotype effects on human midbrain serotonin transporter binding sites and mRNA levels. Am J Psychiatry. 1998;155(2):207-213.

10. Rothman RB, Baumann MH, Dersch CM, et al. Amphetamine-type central nervous system stimulants release norepinephrine more potently than they release dopamine and serotonin. Synapse. 2001;39(1): $32-41$.

11. Heils A, Teufel A, Petri S, et al. Allelic variation of human serotonin transporter gene expression. Journal Neurochem. 1996;66(6): 2621-2624.

12. Hranilovic D, Stefulj J, Schwab S, et al. Serotonin transporter promoter and intron 2 polymorphisms: relationship between allelic variants and gene expression. Biol Psychiatry. 2004;55(11):1090-1094.

13. Bah J, Lindstrom M, Westberg L, et al. Serotonin transporter gene polymorphisms: effect on serotonin transporter availability in the brain of suicide attempters. Psychiatry Res. 2008;162(3):221-229.

14. Fiskerstrand CE, Lovejoy EA, Quinn JP. An intronic polymorphic domain often associated with susceptibility to affective disorders has allele dependent differential enhancer activity in embryonic stem cells. FEBS Lett. 1999;458(2):171-174.

15. MacKenzie A, Quinn J. A serotonin transporter gene intron 2 polymorphic region, correlated with affective disorders, has allele-dependent differential enhancer-like properties in the mouse embryo. Proc Natl Acad Sci U S A. 1999;96(26):15251-15255

16. Feinn R, Nellissery M, Kranzler HR. Meta-analysis of the association of a functional serotonin transporter promoter polymorphism with alcohol dependence. Am J Med Genet B Neuropsychiatr Genet. Feb 5 2005;133B(1):79-84.

17. Hu XZ, Lipsky RH, Zhu G, et al. Serotonin transporter promoter gainof-function genotypes are linked to obsessive-compulsive disorder. $\mathrm{Am}$ J Hum Genet. 2006;78(5):815-826.

18. Rasmussen H, Bagger Y, Tanko LB, Christiansen C, Werge T. Lack of association of the serotonin transporter gene promoter region polymorphism, 5-HTTLPR, including rs25531 with cigarette smoking and alcohol consumption. Am J Med Genet B Neuropsychiatr Genet. 2009;150B(4):575-580.

19. Olsson CA, Byrnes GB, Lotfi-Miri M, et al. Association between 5-HTTLPR genotypes and persisting patterns of anxiety and alcohol use: results from a 10-year longitudinal study of adolescent mental health. Mol Psychiatry. 2005;10(9):868-876.

20. Kaufman J, Yang BZ, Douglas-Palumberi H, et al. Genetic and environmental predictors of early alcohol use. Biol Psychiatry. 2007;61(11):1228-1234.

21. Covault J, Tennen H, Armeli S, et al. Interactive effects of the serotonin transporter 5-HTTLPR polymorphism and stressful life events on college student drinking and drug use. Biol Psychiatry. 2007;61(5): 609-616.

22. McHugh RK, Hofmann SG, Asnaani A, Sawyer AT, Otto MW. The serotonin transporter gene and risk for alcohol dependence: a metaanalytic review. Drug Alcohol Depend. 2010;108(1-2):1-6.

23. Florez G, Saiz P, Garcia-Portilla P, et al. Association between the Stin2 VNTR polymorphism of the serotonin transporter gene and treatment outcome in alcohol-dependent patients. Alcohol Alcohol. 2008;43(5):516-522.

24. Saiz PA, Garcia-Portilla MP, Florez G, et al. Differential role of serotonergic polymorphisms in alcohol and heroin dependence. Prog Neuropsychopharmacol Biol Psychiatry. 2009;33(4):695-700.

25. Ishikawa $\mathrm{H}$, Ohtsuki $\mathrm{T}$, Ishiguro $\mathrm{H}$, et al. Association between serotonin transporter gene polymorphism and smoking among Japanese males. Cancer Epidemiol Biomarkers Prev. 1999;8(9):831-833.

26. Kremer I, Bachner-Melman R, Reshef A, et al. Association of the serotonin transporter gene with smoking behavior. Am J Psychiatry. 2005;162(5):924-930. 
27. Chu SL, Xiao D, Wang C, Jing H. Association between 5-hydroxytryptamine transporter gene-linked polymorphic region and smoking behavior in Chinese males. Chin Med J (Engl). 2009;122(12):1365-1368.

28. Nilsson KW, Oreland L, Kronstrand R, Leppert J. Smoking as a product of gene-environment interaction. Ups J Med Sci. 2009;114(2): 100-107.

29. Hu S, Brody CL, Fisher C, et al. Interaction between the serotonin transporter gene and neuroticism in cigarette smoking behavior. Mol Psychiatry. 2000;5(2):181-188.

30. Gerra G, Garofano L, Zaimovic A, et al. Association of the serotonin transporter promoter polymorphism with smoking behavior among adolescents. Am J Med Genet B Neuropsychiatr Genet. 2005;135B(1):73-78.

31. Lerman C, Caporaso NE, Audrain J, Main D, Boyd NR, Shields PG. Interacting effects of the serotonin transporter gene and neuroticism in smoking practices and nicotine dependence. Mol Psychiatry. 2000;5(2):189-192.

32. Trummer O, Koppel H, Wascher TC, et al. The serotonin transporter gene polymorphism is not associated with smoking behavior. Pharmacogenomics J. 2006;6(6):397-400.

33. Iordanidou M, Tavridou A, Petridis I, et al. Association of polymorphisms of the serotonergic system with smoking initiation in Caucasians Drug Alcohol Depend. 2010;108(1-2):70-76.

34. Gerra G, Garofano L, Santoro G, et al. Association between low-activity serotonin transporter genotype and heroin dependence: behavioral and personality correlates. Am J Med Genet B Neuropsychiatr Genet. 2004;126B(1):37-42.

35. Mannelli P, Patkar AA, Murray HW, et al. Polymorphism in the serotonin transporter gene and response to treatment in African American cocaine and alcohol-abusing individuals. Addiction Biol. 2005;10(3):261-268.

36. Patkar AA, Berrettini WH, Hoehe M, et al. Serotonin transporter (5-HTT) gene polymorphisms and susceptibility to cocaine dependence among African-American individuals. Addiction Biol. 2001;6(4):337-345.

37. Szilagyi A, Boór K, Székely A, et al. Combined effect of promoter polymorphisms in the dopamine D4 receptor and the serotonin transporter genes in heroin dependence. Neuropsychopharmacol Hung 2005;7(1):28-33.

38. Koob GF. Drugs of abuse: anatomy, pharmacology and function of reward pathways. Trends Pharmacol Sci. 1992;13(5):177-184.

39. Jin H, Oksenberg D, Ashkenazi A, et al. Characterization of the human 5-hydroxytryptamine1B receptor. J Biol Chem. 1992;267(9): $5735-5738$.

40. Lappalainen J, Dean M, Charbonneau L, Virkkunen M, Linnoila M, Goldman D. Mapping of the serotonin 5-HT1D beta autoreceptor gene on chromosome 6 and direct analysis for sequence variants. Am J Med Genet. 1995;60(2):157-161.

41. Sanders AR, Duan J, Gejman PV. DNA variation and psychopharmacology of the human serotonin receptor 1B (HTR1B) gene. Pharmacogenomics. 2002;3(6):745-762.

42. Lappalainen J, Long JC, Eggert M, et al. Linkage of antisocial alcoholism to the serotonin 5-HT1B receptor gene in 2 populations. Arch Gen Psychiatry. 1998;55(11):989-994.

43. Huang YY, Grailhe R, Arango V, Hen R, Mann JJ. Relationship of psychopathology to the human serotonin1B genotype and receptor binding kinetics in postmortem brain tissue. Neuropsychopharmacology. 1999;21(2):238-246.

44. Fehr C, Grintschuk N, Szegedi A, et al. The HTR1B 861G $>$ C receptor polymorphism among patients suffering from alcoholism, major depression, anxiety disorders and narcolepsy. Psychiatry Res. 2000;97(1):1-10.

45. Sander T, Ostapowicz A, Samochowiec J, et al. Evaluation of an allelic association of the serotonin 5-HT1B G681C polymorphism with antisocial alcoholism in the German population. Addict Biol. 2000;5(2):167-172.
46. Kranzler HR, Hernandez-Avila CA, Gelernter J. Polymorphism of the 5-HT1B receptor gene (HTR1B): strong within-locus linkage disequilibrium without association to antisocial substance dependence. Neuropsychopharmacology. 2002;26(1):115-122.

47. Sun HF, Chang YT, Fann CS, et al. Association study of novel human serotonin 5-HT(1B) polymorphisms with alcohol dependence in Taiwanese Han. Biol Psychiatry. 2002;51(11):896-901.

48. Cao JX, Hu J, Ye XM, et al. Association between the 5-HTR1B gene polymorphisms and alcohol dependence in a Han Chinese population. Brain Res. 2011;1376:1-9.

49. Edwards AC, Aliev F, Bierut LJ, et al. Genome-wide association study of comorbid depressive syndrome and alcohol dependence. Psychiatr Genet. 2012;22(1):31-41.

50. Chen YC, Prescott CA, Walsh D, et al. Different phenotypic and genotypic presentations in alcohol dependence: age at onset matters. J Stud Alcohol Drugs. 2011;72(5):752-762.

51. Conner TS, Jensen KP, Tennen H, Furneaux HM, Kranzler HR, Covault J. Functional polymorphisms in the serotonin 1B receptor gene (HTR1B) predict self-reported anger and hostility among young men. Am J Med Genet B Neuropsychiatr Genet. 2010;153B(1): $67-78$.

52. Cigler T, LaForge KS, McHugh PF, Kapadia SU, Leal SM, Kreek MJ. Novel and previously reported single-nucleotide polymorphisms in the human 5-HT(1B) receptor gene: no association with cocaine or alcohol abuse or dependence. Am J Med Genet. 2001;105(6):489-497.

53. Lerer E, Kanyas K, Karni O, Ebstein RP, Lerer B. Why do young women smoke? II. Role of traumatic life experience, psychological characteristics and serotonergic genes. Mol Psychiatry. 2006;11(8): 771-781.

54. Ujike H, Kishimoto M, Okahisa Y, et al. Association between $5 \mathrm{HT} 1 \mathrm{~b}$ receptor gene and methamphetamine dependence. Curr Neuropharmacol. 2011;9(1):163-168.

55. Hoyer D, Hannon JP, Martin GR. Molecular, pharmacological and functional diversity of 5-HT receptors. Pharmacol Biochem Behav. 2002;71(4):533-554.

56. Hoyer D, Martin GR. Classification and nomenclature of 5-HT receptors: a comment on current issues. Behav Brain Res. 1996;73(1-2): 263-268.

57. Alex KD, Pehek EA. Pharmacologic mechanisms of serotonergic regulation of dopamine neurotransmission. Pharmacol Ther. 2007;113(2):296-320.

58. Fink KB, Gothert M. 5-HT receptor regulation of neurotransmitter release. Pharmacoll Rev. 2007;59(4):360-417.

59. Parsons MJ, D'Souza UM, Arranz MJ, Kerwin RW, Makoff AJ. The-1438A/G polymorphism in the 5-hydroxytryptamine type $2 \mathrm{~A}$ receptor gene affects promoter activity. Biol Psychiatry. 2004;56(6): 406-410.

60. Nakamura T, Matsushita S, Nishiguchi N, Kimura M, Yoshino A, Higuchi S. Association of a polymorphism of the 5HT2A receptor gene promoter region with alcohol dependence. Mol Psychiatry. 1999;4(1):85-88.

61. Schuckit MA, Mazzanti C, Smith TL, et al. Selective genotyping for the role of 5-HT2A, 5-HT2C, and GABA alpha 6 receptors and the serotonin transporter in the level of response to alcohol: a pilot study. Biol Psychiatry. 1999;45(5):647-651.

62. Drago A, Liappas I, Petio C, et al. Epistasis between IL1A, IL1B, TNF, HTR2A, 5-HTTLPR and TPH2 variations does not impact alcohol dependence disorder features. Int J Environ Res Public Health. 2009;6(7):1980-1990.

63. Polina ER, Contini V, Hutz MH, Bau CH. The serotonin 2A receptor gene in alcohol dependence and tobacco smoking. Drug Alcohol Depend. 2009;101(1-2):128-131.

64. Huang S, Cook DG, Hinks LJ, et al. CYP2A6, MAOA, DBH, DRD4, and 5HT2A genotypes, smoking behaviour and cotinine levels in 1518 UK adolescents. Pharmacogenet Genomics. 2005;15(12): $839-850$. 
65. Li T, Liu X, Zhao J, et al. Allelic association analysis of the dopamine D2, D3, 5-HT2A, and GABA(A) gamma 2 receptors and serotonin transporter genes with heroin abuse in Chinese subjects. Am J Med Genet. 2002;114(3):329-335.

66. Terrazzino S, Sances G, Balsamo F, et al. Role of 2 common variants of 5HT2A gene in medication overuse headache. Headache. 2010;50(10):1587-1596.

67. Callahan PM, Cunningham KA. Modulation of the discriminative stimulus properties of cocaine by 5-HT1B and 5-HT2C receptors. J Pharmacol Exp Ther. 1995;274(3):1414-1424.

68. Frankel PS, Cunningham KA. m-Chlorophenylpiperazine (mCPP) modulates the discriminative stimulus effects of cocaine through actions at the 5-HT2C receptor. Behav Neurosci. 2004;118(1):157-162.

69. Filip M, Faron-Gorecka A, Kusmider M, Golda A, Frankowska M, Dziedzicka-Wasylewska M. Alterations in BDNF and trkB mRNAs following acute or sensitizing cocaine treatments and withdrawal. Brain Res. 2006;1071(1):218-225.

70. Nyholt DR, Curtain RP, Griffiths LR. Familial typical migraine: significant linkage and localization of a gene to Xq24-28. Hum Genet. 2000;107(1): 18-23.

71. Lappalainen J, Zhang L, Dean M, et al. Identification, expression, and pharmacology of a Cys23-Ser23 substitution in the human 5-HT2c receptor gene (HTR2C). Genomics. 1995;27(2):274-279.

72. Lappalainen J, Long JC, Virkkunen M, Ozaki N, Goldman D, Linnoila M. HTR2C Cys23Ser polymorphism in relation to CSF monoamine metabolite concentrations and DSM-III-R psychiatric diagnoses. Biol Psychiatry. 1999;46(6):821-826.

73. Jonsson EG, Bah J, Melke J, et al. Monoamine related functional gene variants and relationships to monoamine metabolite concentrations in CSF of healthy volunteers. BMC Psychiatry. 2004;4:4.

74. Himei A, Kono Y, Yoneda H, et al. An association study between alcoholism and the serotonergic receptor genes. Alcohol Clin Exp Res. 2000;24(3):341-342.

75. Mottagui-Tabar S, McCarthy S, Reinemund J, Andersson B, Wahlestedt C, Heilig M. Analysis of 5-hydroxytryptamine 2c receptor gene promoter variants as alcohol-dependence risk factors. Alcohol Alcohol. 2004;39(5):380-385.

76. Derkach V, Surprenant A, North RA. 5-HT3 receptors are membrane ion channels. Nature. 1989;339(6227):706-709.

77. Liu W, Thielen RJ, Rodd ZA, McBride WJ. Activation of serotonin-3 receptors increases dopamine release within the ventral tegmental area of Wistar and alcohol-preferring (P) rats. Alcohol. 2006;40(3):167-176.

78. Mihic SJ, Ye Q, Wick MJ, et al. Sites of alcohol and volatile anaesthetic action on GABA(A) and glycine receptors. Nature. 1997; 389(6649):385-389.

79. Niesler B, Frank B, Kapeller J, Rappold GA. Cloning, physical mapping and expression analysis of the human 5-HT3 serotonin receptor-like genes HTR3C, HTR3D and HTR3E. Gene. 2003;310:101-111.

80. Davies PA, Pistis M, Hanna MC, et al. The 5-HT3B subunit is a major determinant of serotonin-receptor function. Nature. 1999;397(6717): 359-363.

81. Levran O, Londono D, O'Hara K, et al. Genetic susceptibility to heroin addiction: a candidate gene association study. Genes Brain Behav. 2008;7(7):720-729.

82. Ducci F, Enoch MA, Yuan Q, et al. HTR3B is associated with alcoholism with antisocial behavior and alpha EEG power - an intermediate phenotype for alcoholism and co-morbid behaviors. Alcohol. 2009;43(1):73-84.

83. Enoch MA, Gorodetsky E, Hodgkinson C, Roy A, Goldman D. Functional genetic variants that increase synaptic serotonin and 5-HT3 receptor sensitivity predict alcohol and drug dependence. Mol Psychiatry. 2011;16(11):1139-1146.

84. Krzywkowski K, Davies PA, Feinberg-Zadek PL, BraunerOsborne H, Jensen AA. High-frequency HTR3B variant associated with major depression dramatically augments the signaling of the human 5-HT3AB receptor. Proc Natl Acad Sci U S A. 2008;105(2):722-727.
85. Walstab J, Hammer C, Bonisch H, Rappold G, Niesler B. Naturally occurring variants in the HTR3B gene significantly alter properties of human heteromeric 5-hydroxytryptamine-3A/B receptors. Pharmacogenet Genomics. 2008;18(9):793-802.

86. Hendershot CS, Witkiewitz K, George WH, Marlatt GA. Relapse prevention for addictive behaviors. Subst Abuse Treat Prev Policy. 2011;6:17.

87. Johnson BA, Ait-Daoud N, Ma JZ, Wang Y. Ondansetron reduces mood disturbance among biologically predisposed, alcohol-dependent individuals. Alcohol Clin Exp Res. 2003;27(11):1773-1779.

88. Johnson BA, Roache JD, Ait-Daoud N, Zanca NA, Velazquez M. Ondansetron reduces the craving of biologically predisposed alcoholics. Psychopharmacology. 2002;160(4):408-413.

89. Johnson BA, Roache JD, Javors MA, et al. Ondansetron for reduction of drinking among biologically predisposed alcoholic patients: a randomized controlled trial. JAMA. 2000;284(8): 963-971.

90. Johnson BA, Ait-Daoud N, Seneviratne C, et al. Pharmacogenetic approach at the serotonin transporter gene as a method of reducing the severity of alcohol drinking. Am J Psychiatry. 2011;168(3): 265-275.

91. Kenna GA, Zywiak WH, McGeary JE, et al. A within-group design of nontreatment seeking 5-HTTLPR genotyped alcohol-dependent subjects receiving ondansetron and sertraline. Alcohol Clin Exp Res. 2009;33(2):315-323.

92. Kranzler HR, Armeli S, Tennen H. Post-treatment outcomes in a double-blind, randomized trial of sertraline for alcohol dependence. Alcohol Clin Exp Res. 2012;36(4):739-744.

93. Muhonen LH, Lahti J, Alho H, Lonnqvist J, Haukka J, Saarikoski ST. Serotonin transporter polymorphism as a predictor for escitalopram treatment of major depressive disorder comorbid with alcohol dependence. Psychiatry Res. 2011;186(1):53-57.

94. Wong WM, Hasemann S, Schwarz M, et al. Citalopram neuropharmacological challenge in alcohol-dependent patients and controls: pharmacogenetic, endocrine and psychobehavioral results. Pharmacopsychiatry. 2008;41(2):72-78.

95. Aoki J, Hayashida M, Tagami M, et al. Association between 5-hydroxytryptamine $2 \mathrm{~A}$ receptor gene polymorphism and postoperative analgesic requirements after major abdominal surgery. Neurosci Lett. 2010;479(1):40-43.

96. Kosek E, Jensen KB, Lonsdorf TB, Schalling M, Ingvar M. Genetic variation in the serotonin transporter gene (5-HTTLPR, rs25531) influences the analgesic response to the short acting opioid Remifentanil in humans. Mol Pain. 2009;5:37.

97. Munafo MR, Johnstone EC, Wileyto EP, Shields PG, Elliot KM, Lerman C. Lack of association of 5-HTTLPR genotype with smoking cessation in a nicotine replacement therapy randomized trial. Cancer Epidemiol Biomarkers Prev. 2006;15(2):398-400.

98. David SP, Munafo MR, Murphy MF, Walton RT, Johnstone EC. The serotonin transporter 5-HTTLPR polymorphism and treatment response to nicotine patch: follow-up of a randomized controlled trial. Nicotine Tob Res. 2007;9(2):225-231.

99. David SP, Johnstone EC, Murphy MF, et al. Genetic variation in the serotonin pathway and smoking cessation with nicotine replacement therapy: new data from the Patch in Practice trial and pooled analyses. Drug Alcohol Depend. 2008;98(1-2):77-85.

100. Lesch KP, Bengel D, Heils A, et al. Association of anxiety-related traits with a polymorphism in the serotonin transporter gene regulatory region. Science. 1996;274(5292):1527-1531.

101. Duan J, Sanders AR, Molen JE, et al. Polymorphisms in the $5^{\prime}$-untranslated region of the human serotonin receptor $1 \mathrm{~B}$ (HTR1B) gene affect gene expression. Mol Psychiatry. 2003;8(11): 901-910.

102. Arranz M, Collier D, Sodhi M, et al. Association between clozapine response and allelic variation in 5-HT2A receptor gene. Lancet. 1995;346(8970):281-282. 
103. Polesskaya OO, Aston C, Sokolov BP. Allele C-specific methylation of the 5-HT2A receptor gene: evidence for correlation with its expression and expression of DNA methylase DNMT1. J Neuroscience Res. 2006;83(3):362-373.
104. Okada M, Northup JK, Ozaki N, Russell JT, Linnoila M, Goldman D Modification of human 5-HT(2C) receptor function by Cys23Ser, an abundant, naturally occurring amino-acid substitution. Mol Psychiatry. 2004;9(1):55-64.

\section{Publish your work in this journal}

Substance Abuse and Rehabilitation is an international, peer-reviewed, open access journal publishing original research, case reports, editorials, reviews and commentaries on all areas of addiction and substance abuse and options for treatment and rehabilitation. The manuscript management system is completely online and includes a very quick and fair peer-review system. Visit http://www.dovepress.com/testimonials.php to read real quotes from published authors. 